\title{
EVALUATION OF THE PROTEIN QUALITY OF BEANS, CORN, AND WHEAT GRAINS INFESTED BY INSECT PESTS
}

\author{
FABRÍCIA QUEIROZ MENDES ${ }^{1 *}$ \\ MARIA GORETI DE ALMEIDA OLIVEIRA ${ }^{2 * *}$ \\ NEUZA MARIA BRUNORO COSTA ${ }^{3^{\text {t*x+}}}$ \\ FLÁVIA REGINA PASSOS $4^{4 *+* *}$ \\ JOSÉ CÉSAR ROSA $5^{\text {t*x+*x}}$ \\ RAUL NARCISO CARVALHO GUEDES $6^{*+* x+* * *}$ \\ JOEL ANTÔNIO DE OLIVEIRA
}

\begin{abstract}
Insect infestation of grains causes several types of damage, including reduced grain weight, heat damage and consequent deterioration, diminished market value, and decreased nutritional value due to grain consumption by insects. The goal of this study was to compare the digestibility, chemical score, protein digestibility corrected amino acid score (PDCAAS), protein efficiency ratio (PER), and net protein ratio (NPR) of infested and uninfested grain flours. This study found that infested grain flours had higher nitrogen contents than uninfested grain flours. The presence of insects did not alter the digestibility of the analyzed grains. However, insects decreased the PER and NPR for beans but not corn and wheat. Similarly, there was a greater reduction in the levels of essential amino acids for beans than for corn and wheat. Insect infestation reduces the nutritional quality of grains, although the type of insect and the grain quality determine the extent of this reduction.
\end{abstract}

KEY-WORDS: INSECT PESTS; PROTEIN DIGESTIBILITY; CHEMICAL SCORE.

1 D.Sc. em Bioquímica Agrícola, Universidade Federal de Viçosa, Viçosa, MG (e-mail: fabricia.mendes@ ufv.br)

$2 \quad{ }^{*}$ D.Sc. em Bioquímica e Imunologia, Universidade Federal de Viçosa, Viçosa, MG (e-mail: malmeida@ufv. br)

$3{ }^{\star \star \star}$ D.Sc. em Ciência e Tecnologia de Alimentos, Universidade Federal do Espírito Santo, Alegre, ES (e-mail: neuzambc@gmail.com)

$4{ }^{* * *}$ M.Sc. em Agronomia (Produção Vegetal), Universidade Federal de Viçosa Campus de Rio Paranaíba, Rio Paranaíba, MG (e-mail: flaviapassos1@yahoo.com.br)

$5 \quad$ D.Sc. em Química, Universidade de São Paulo, Ribeirão Preto, SP (e-mail: jcrosa@fmrp.usp.br)

$6 \quad$ D.Sc. em Entomologia, Universidade Federal de Viçosa, Viçosa, MG (e-mail: guedes@ufv.br; joel@ufv. br) 


\section{INTRODUCTION}

Beans, corn, and wheat are important sources of carbohydrates, proteins, minerals, and vitamins. During storage, these grains can be attacked by several types of insect pests. It is estimated that in Brazil, 10 to $15 \%$ of grain production is lost annually due to insect infestation. Damages by insects include reduced grain weight, heat damage and consequent deterioration, and the loss of market and nutritional value due to insect consumption (Athié et al., 1998).

Chemical analyses of grains attacked by insects have revealed a loss of nutrients such as carbohydrates, vitamins, and minerals. According Jood, Kapoor and Singh (1992), the total amount of protein, non-protein nitrogen, and uric acid are increased in grains infested by insects. However, Lale and Igwebuike (2002) reported a decrease in the protein content with increased infestation. Chemical analyses can be used to determine the total nitrogen content, nitrogenous substances excluding toxic insect excreta, insect body fragments, and protease inhibitors in grain. The analysis of the biological value of grains that have been infested by insects is necessary to determine their protein quality.

Classical methods for determining protein quality include assessments of the protein efficiency ratio (PER), nitrogen balance, biological value, chemical score, digestibility, and protein digestibility corrected amino acid score (PDCAAS). The PDCAAS was introduced by the FAO/WHO in 1985 and is the preferred method for evaluating protein quality. The PDCAAS is defined as the ratio of the content of the first limiting amino acid in the protein $(\mathrm{mg} / \mathrm{g})$ to the contents of that amino acid in the reference protein $(\mathrm{mg} / \mathrm{g})$, multiplied by the true digestibility percentage. According to the $\mathrm{FAO} / \mathrm{WHO}$, the reference standard is the essential amino acid requirement for children between 2 and 5 years of age (1985) (MILLWARD et al., 2008).

This study aimed to evaluate the digestibility, chemical score, PDCAAS, PER, and net protein ratio (NPR) of infested and uninfested bean, corn, and wheat flour.

\section{MATERIALS AND METHODS}

\subsection{EXPERIMENT SITE}

This work was developed at the Laboratory of Enzymology, Biochemistry of Proteins and Peptides, Institute of Biotechnology Applied to Agriculture (BIOAGRO), and the Laboratory of Experimental Nutrition, Department of Nutrition and Health (DNS) of the Federal University of Viçosa (UFV), Viçosa, Minas Gerais.

\subsection{GRAIN INFESTATION AND PREPARATION OF SAMPLES}

Bean grains were packed into glass vials having a $1 \mathrm{~kg}$ capacity. To create a sample of infested bean grains, $500 \mathrm{~g}$ of grain and 50 adult Acanthoscelides obtectus insects were placed in each vial. Each vial was then closed with a cover screen to ensure oxygen exposure and insect survival. The vials were kept at the ambient temperature and humidity level.

Corn and wheat grains were packed into glass vials having a $3 \mathrm{~kg}$ capacity. To create a sample of infested corn and wheat grains, approximately $2 \mathrm{~kg}$ of grain and 200 Sitophilus zeamais adults were placed into each vial. The vials were kept at the ambient temperature and humidity level.

To evaluate the percentage of grains attacked by the insects, samples of 100 grains were immersed in water for $24 \mathrm{~h}$ to soften the grains. The grains were then cut and examined individually. Grains containing larva, pupa, or adult insects and those with insect exit holes were considered infested in accordance with the recommendations of the Rules for Testing Seeds (BRAZIL, 1992).

After the storage period, infested and uninfested Jalo and Radiante bean grains were cooked for $40 \mathrm{~min}$ in a domestic pressure cooker containing water at a ratio of 1:2 (w/v). After cooking, the grains were dried in an oven with an air circulation at $60^{\circ} \mathrm{C}$ for $24 \mathrm{~h}$. The grains were then milled using a food processor (Arno brand, FP15 model, São Paulo, SP, Brazil) and sifted through a mesh sieve (1 mm).

To obtain corn flour, the infested and uninfested corn samples were milled using a hammer 
mill and sifted through a mesh sieve $(1 \mathrm{~mm})$.

To obtain wheat flour, grains were placed in an oven at $105^{\circ} \mathrm{C}$ (AOAC, 2012). The samples were conditioned to a moisture content of $15.5 \%$. After 20 to $24 \mathrm{~h}$, the grains were ground using a mill (Brabender Quadrumat Senior, Duisburg, Germany).

\subsection{EVALUATION OF THE NUTRITIONAL QUALITY OF GRAINS DAMAGED BY INSECTS}

\subsubsection{Determination of nitrogen contents}

The protein content of each sample was determined using the Kjeldhal semi-micro method according to the AOAC (2012). A factor of 6.25 was used in the calculation of nitrogen conversion to proteins.

\subsubsection{Biological assay}

Non-protein diets, casein diets (standard), and test diets were prepared using the studied protein samples, as shown in Table 1.

The composition of the diets was based on the AIN-93G rodent diet according to Reeves, Nielsen and Fahey (1993). The protein content of the casein diet was altered to $9.5 \%$ (standard), and the protein content of the corn and wheat diet was altered to $7 \%$.

To create iso-caloric and iso-protein diets, the quantities of other diet ingredients (starch, dextrinized starch, sucrose, oil and cellulose) were also changed according to the composition of the tested foods (Table 1).

After preparing samples based on the protein content of each diet, diet samples were placed in polyethylene bags, appropriately labeled, and stored in a refrigerator. A total of 66 newly weaned male Wistar rats were used. The average age of the animals was 23 days with a weight of 50 to 60 g. The animals were obtained from the Health and Biological Sciences Center (CBB) nursery of the Federal University of Viçosa (UFV).

The animals were assigned to 10 groups with six animals in each group. The difference between the average weight within the various groups did not exceed $10 \mathrm{~g}$. The rats were placed in individual cages, where they received water and food ad libitum for 14 days. The body temperature of the animals was maintained at $22 \pm 3^{\circ} \mathrm{C}$, and their food intake and body weight was monitored weekly.

The experiment was conducted in accordance with the rules of the Brazilian College for Animal Experimentation (COBEA) and international rules.

\subsubsection{True digestibility}

To determine the grain digestibility, the diets were dyed with indigo carmine at $100 \mathrm{mg} / 100$ $\mathrm{g}$ and offered to the animals on the $7^{\text {th }}$ and $10^{\text {th }}$ days of the study. The rat excrement was collected in individual pots on the $8^{\text {th }}$ through $11^{\text {th }}$ days and refrigerated. On the $8^{\text {th }}$ day, only the excrement containing dye was collected. On the $9^{\text {th }}$ and $10^{\text {th }}$ days, all excrement was collected. On the $11^{\text {th }}$ day, only excrement containing dye was collected.

At the end of the experiment, the fecal samples were dried in a sterilizer with air circulation at $105^{\circ} \mathrm{C}$ for $24 \mathrm{~h}$. The fecal samples were then cooled, weighed, and ground in a food processor (Arno brand, FP15 model, São Paulo, SP, Brazil) to determine their nitrogen contents using the Kjeldahl semi-micro method with triplicate samples.

The true digestibility (TD) was calculated by measuring the quantity of nitrogen that was ingested via the subjects' diet, the quantity that was eliminated in excrement, and the metabolic loss of excrement, which corresponds to the fecal nitrogen content of the group with a non-protein diet. The TD was calculated using Equation 1:

$$
\% \text { Digestibility }=\frac{I-(F-K)}{I}
$$

Where:

$\mathrm{I}=$ Nitrogen ingested by the test group.

$\mathrm{F}=$ Fecal nitrogen of the test group.

FK $=$ Fecal nitrogen of the group with a non-protein diet 


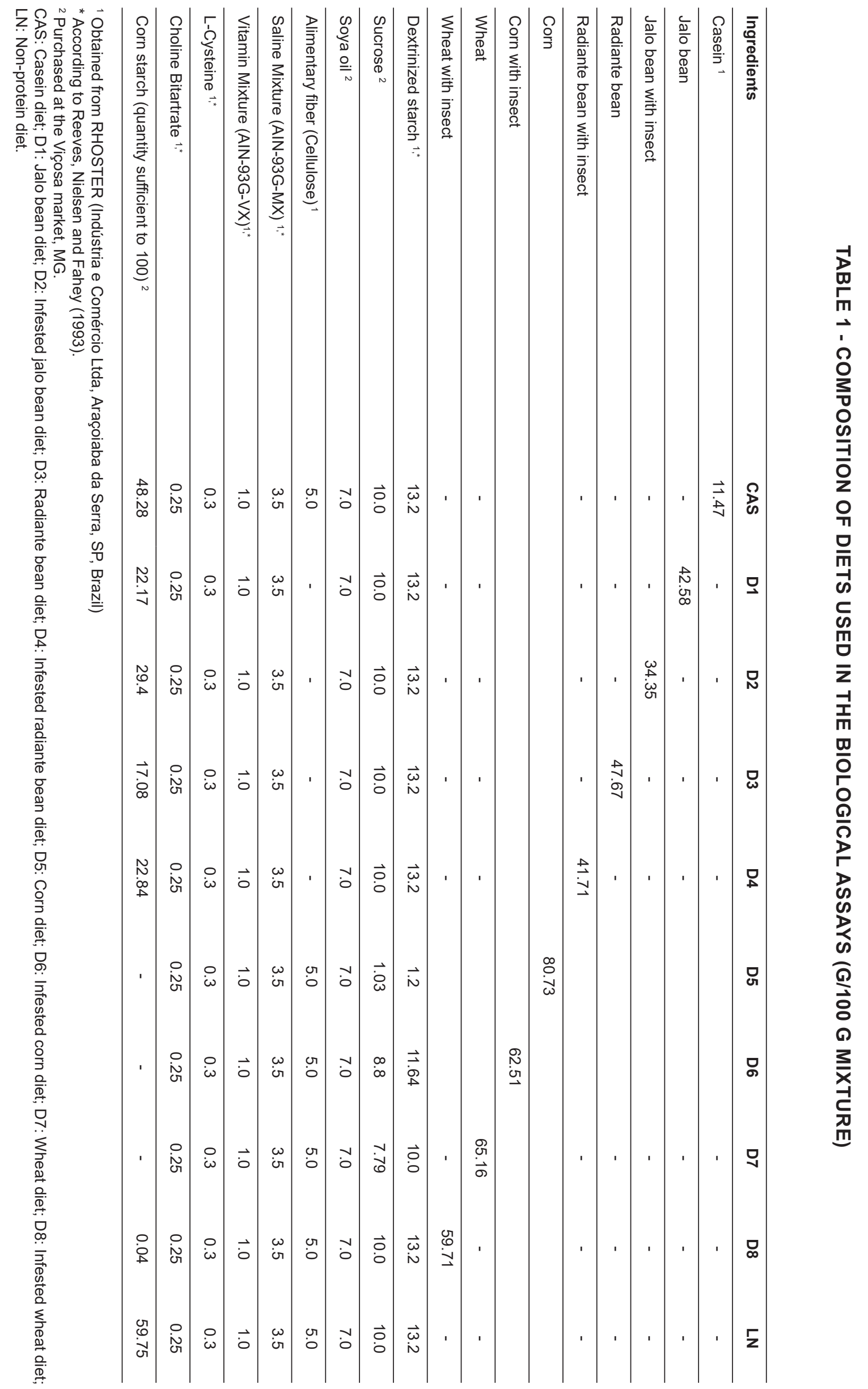




\subsubsection{Protein efficiency ratio}

The PER was determined using a method developed by Osborne, Mendel and Ferry according to the AOAC (2012). The method considers the weight gain of the animal and the protein consumption.

The PER was calculated using Equation 2:

$$
P E R=\frac{\text { weight gain group }- \text { test }(\mathrm{g})}{\text { protein consumed by the group - test }(\mathrm{g})}
$$

\subsubsection{Net protein ratio}

The NPR was determined according to the method of Bender and Doell (1957). The NPR was calculated on the $14^{\text {th }}$ day of the experiment based on the test group's weight gain and the nonprotein group's weight loss, compared to the protein consumption the test group.

The NPR was calculated using Equation 3:

$$
N P R=\frac{\text { weight gain group }- \text { test }(\mathrm{g})+\text { weight loss group non }- \text { proteic }(\mathrm{g})}{\text { protein consumed by the group }- \text { test }(\mathrm{g})}
$$

\subsubsection{Determination and quantification of amino acids}

The amino acid compositions were determined on samples hydrolyzed with hydrochloric acid $(6 \mathrm{~N}$ redistilled $\mathrm{HCl}$ ) followed by pre-column derivation using phenyl isothiocyanate (PITC) and reversed-phase C18 column separation (Pico-Tag - $3.9 \times 150 \mathrm{~mm}$ ) of the phenylthiocarbamyl amino acids derivatives (PTC-AA). The sample quantification was based on the peak area of each amino acid detected at $254 \mathrm{~nm}$; the peak area of a known concentration of a standard amino acid was used as a reference. The standard was derived under the same conditions and at the same time as the samples (Pires et al., 2006).

\subsubsection{Protein digestibility corrected amino acid score (PDCAAS)}

The measured nitrogen contents, protein contents, essential amino acid contents, amino acid score (FAO / WHO, 1985), and true digestibility were used to calculate the PDCAAS values.

The PDCAAS was calculated by multiplying each score by the protein digestibility of the essential amino acid having the lowest chemical score. A PDCAAS value of less than 1.0 was considered to be a valid score (Henley and Kuster, 1994).

\subsection{STATISTICAL DESIGN}

An analysis of variance (ANOVA) was used to determine the F-values. For significant values, we used the Tukey test at $5 \%$ probability to compare the means of the qualitative variables. The System for Statistical and Genetic Analysis (SAEG) software was used for the statistical analyses.

\section{RESULTS AND DISCUSSION}

\subsection{GRAIN INFESTATION}

The degree of grain infestation (GI) among the analyzed grains showed that the uninfested grain samples remained uninfested throughout the study period. The infestation of grains in the presence of insect pests increased during the infestation period. After 84 days of storage, the Jalo bean had a $91.33 \%$ infestation rate, and the Radiante bean had an $80 \%$ infestation rate. After 72 days of storage, the corn had a $90.67 \%$ infestation rate, and the wheat grain had a $65.33 \%$ infestation rate. 


\subsection{THE NUTRITIONAL QUALITY OF GRAINS ATTACKED BY INSECT PESTS}

The protein contents (dry basis) of the bean flour, corn, and wheat are presented in Table 2.

TABLE 2 - PROTEIN CONTENT (\% DRY BASIS OF BEAN, CORN AND WHEAT FLOUR SAMPLES

\begin{tabular}{lcc}
\hline & Without insects & With insects \\
\hline Jalo bean & $23.89 \mathrm{Ba}$ & $29.46 \mathrm{Aa}$ \\
\hline Radiante bean & $21.77 \mathrm{Bb}$ & $25.14 \mathrm{Ab}$ \\
\hline Corn & $10.12 \mathrm{Bd}$ & $12.05 \mathrm{Ac}$ \\
\hline Wheat & $12.49 \mathrm{Ac}$ & $12.60 \mathrm{Ac}$ \\
\hline
\end{tabular}

$A B$ Means followed by the same capital letter in the same row do not differ at $5 \%$ probability according to the F-test. ab Means followed by the same lowercase letter in the same column do not differ at $5 \%$ probability based on the Tukey test.

The protein contents of the bean and corn samples increased significantly $(p<0.05)$ with insect infestation. Breathing insects release carbon in the form of gas $\left(\mathrm{CO}_{2}\right)$ and water. However, the nitrogen present in the grains is not released when insects breathe and is used by insects for the production of proteins or is excreted. Because nitrogen excreted by the insect remains in the grain sample, and carbon is removed as a gas, there is an increased concentration of nitrogen relative to the total grain weight. Therefore, higher nitrogen and protein contents were observed in infested samples. In addition, the larvae of insects feed directly on grains, assimilating and concentrating the protein compounds. Thus, the presence of insects remaining within the grains, especially insects in the larval and pupa stages, contributes to the high protein levels measured in infested grains.

Both Barney et al. (1991) and Resende et al. (2007) observed an increase in the total protein level of corn and beans that were stored in the presence of $S$. zeamais and A. obtectus, respectively. However, Lale and Igwebuike (2002) observed a reduction in the protein contents of acacia pods infested by Coleoptera.

The digestibility values of the samples ranged from $71.66 \%$ (Radiante bean) to $94.13 \%$ (casein) (Table 3$)$. The presence of insects did not alter the digestibility $(p>0.05)$.

TABLE 3 - MEANS IN VIVO PROTEIN DIGESTIBILITY OF PROTEIN SAMPLES

\begin{tabular}{lc}
\hline Sources of protein & True digestibility (\%) \\
\hline Casein & $94.13 \mathrm{a}$ \\
\hline Jalo bean & $73.57 \mathrm{c}$ \\
\hline Jalo bean with insect & $74.19 \mathrm{c}$ \\
\hline Radiante bean & $71.66 \mathrm{~d}$ \\
\hline Radiante bean with insect & $71.83 \mathrm{~d}$ \\
\hline Corn & $84.32 \mathrm{c}$ \\
\hline Corn with insect & $84.34 \mathrm{c}$ \\
\hline Wheat & $92.80 \mathrm{ab}$ \\
\hline Wheat with insect & $90.03 \mathrm{~b}$ \\
\hline
\end{tabular}

Means followed by the same letter do not differ based on the Tukey test at $5 \%$ probability. 
The digestibility values determined for casein and wheat are similar to those reported by Pires et al. (2006), which were $93.33 \%$ for casein, and $89.44 \%$ for wheat. Pires et al. (2006) found a slightly higher value for Pearl beans $(78.70 \%)$. This difference may be attributed to their use of different varieties of grain.

Table 3 shows that the digestibility was not affected by the presence of insects. This fact was also reported by Resende et al. (2007), who determined the in vitro digestibility of beans infested by $A$. obtectus during 112 days of storage.

At the end of the storage period, the adult insects were removed, leaving the larva, pupa, and some adult insects inside the grains. In a study of the nutritional value of various species of insects, Ramos-Elorduy et al. (1997) found that the digestibility of insect protein ranged from $76.6 \%$ to $98 \%$. Digestibility values for insects with exoskeletons are lower due to the presence of chitin in their exoskeletons. Removal of the exoskeleton increases the digestibility (VERKERK et al. 2007). Because the majority of adult insects were removed, and adults typically have more rigid exoskeletons, the presence of insects in the studied grain did not affect the digestibility.

Braga et al. (2003) analyzed the digestibility of corn at different levels of decomposition and noted that the true digestibility decreased and then increased (quadratic behavior) with increasing levels of decomposition. However, in a study of the protein quality of sorghum infested with $T$. granarium and $R$. dominica, Jood et al. (1993) observed that the digestibility decreased as the extent of infestation increased. Similar observations were also reported by Modgil and Mehta (1993) in their study of chickpeas infested with Callosobruchus chinensis, Jood et al. (1992) in their study of corn infested by T. granarium and R. dominica, and Jood and Kapoor (1992) in their study of the in vitro digestibility of infested corn, wheat, and sorghum.

PER values are used to indicate the ability of a protein to promote growth in weanling rats. The NPR is a modification of the PER and takes into consideration the weight gain from protein in diet groups and the weight loss of groups with non-protein diets. Both the PER and NPR values of beans were influenced by the presence of insects $(p<0.05)($ Table 4$)$.

TABLE 4 - MEANS PER AND NPR VALUES FOR PROTEIN SAMPLES

\begin{tabular}{lcccc}
\hline & \multicolumn{2}{c}{ PER } & NPR \\
\hline & Without insects & With insects & Without insects & With insects \\
\hline Jalo bean & $2.10 \mathrm{Aa}^{*}$ & $1.58 \mathrm{Ba}^{*}$ & $3.74 \mathrm{Aa}$ & $3.10 \mathrm{Ba}^{*}$ \\
\hline Radiante bean & $2.34 \mathrm{a}^{*}$ & $1.66 \mathrm{Ba}^{*}$ & $3.93 \mathrm{Aa}$ & $3.35 \mathrm{Ba}^{*}$ \\
\hline Corn & $1.37 \mathrm{Ab}^{*}$ & $1.07 \mathrm{Aa}^{*}$ & $2.92 \mathrm{Ab}^{*}$ & $2.94 \mathrm{Aa}^{*}$ \\
\hline Wheat & $0.45 \mathrm{Ac}^{*}$ & $0.58 \mathrm{Ab}^{*}$ & $2.17 \mathrm{Ac}^{*}$ & $2.12 \mathrm{Ab}^{*}$ \\
\hline Casein & & $3.23^{*}$ & & $4.01^{*}$ \\
\hline
\end{tabular}

AB Means followed by the same capital letter in the same row do not differ at $5 \%$ probability based on the F-test. ab Means followed by the same lowercase letter in the same column do not differ at $5 \%$ probability according to the Tukey test. * Significantly different relative to the casein diet $(p<0.05)$.

The PER and NPR values for each protein sample relative to $100 \%$ casein are shown in Table 5. The presence of insects in the beans decreased the PER and NPR values by approximately $20 \%$ and $15 \%$, respectively. The uninfested beans had, on average, approximately $70 \%$ of the casein PER and approximately $95 \%$ of the casein NPR (Table 5). These figures demonstrate that the beans are able to promote the maintenance of body proteins (NPR close to $100 \%$ ), but are not effective in promoting growth (PER approximately $70 \%$ ). Infested wheat flour was both deficient in promoting growth and maintaining body proteins. 
TABLE 5 - AVERAGE PER (\%) AND NPR (\%) VALUES OF THE PROTEIN SAMPLES

\begin{tabular}{lcc}
\hline Protein sources & PER (\%) & NPR(\%) \\
\hline Casein & 100 & 100 \\
\hline Jalo bean & 65.02 & 93.27 \\
\hline Jalo bean with insect & 48.92 & 77.31 \\
\hline Radiante bean & 72.45 & 98.00 \\
\hline Radiante bean with insect & 51.39 & 83.54 \\
\hline Corn & & 72.82 \\
\hline Corn with insect & 42.41 & 73.31 \\
\hline Wheat & 33.13 & 54.11 \\
\hline Wheat with insect & 13.93 & 52.87 \\
\hline
\end{tabular}

The digestibility was not affected by the presence of insect pests (Table 3). However, the PER and NPR for beans decreased in the presence of insect pests (Table 4). These differences were not observed in corn and wheat. Braga et al. (2003) analyzed the contents of rotten corn infested with S. zeamais from 2 to $38 \%$ and found no significant differences in the NPR values. However, Modgil and Mehta (1997) observed a PER reduction in chickpeas infested with C. chinensis. Similar results were observed by Jood et al. (1993), who evaluated sorghum infested by $T$. granarium and $R$. Dominica, Modgil and Mehta (1993), who evaluated chickpeas infested by C. chinensis, and by Jood et al. (1992), who evaluated corn infested by $T$. granarium and $R$. dominica. However, a reduction in NPR values was not observed in these previous studies.

The essential and nonessential amino acids compositions expressed as grams of amino acid per 100 grams of sample are given in Table 6.

To calculate the chemical and PDCAAS values for the amino acid contents, the mg of amino acid per $g$ of protein were calculated and compared to the standard FAO/WHO values (1985) (Table 7). The values obtained were divided by the values recommended by FAO/WHO (1985), and the result (known as a chemical score) allowed us to determine the limiting amino acid in each protein source (Table 8).

The average chemical score values for the infested and uninfested grains are described in Table 9.

A protein having a chemical score greater than 1.0 for all amino acids is considered to have a high nutritional value. An amino acid having a chemical score of less than 1.0 is considered a limiting amino acid.

The PDCAAS values of the samples are shown in Table 10. To calculate the PDCAAS, the chemical score of the most limiting essential amino acid of each protein source was used as a reference (Table 8 ). This value was multiplied by the respective true protein digestibility for the given protein (Table 3). For the Jalo and Radiante bean varieties, sulfur amino acids (methionine and cysteine) were the limiting amino acids, whereas lysine was the limiting amino acid for corn and wheat. 


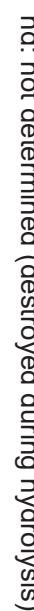

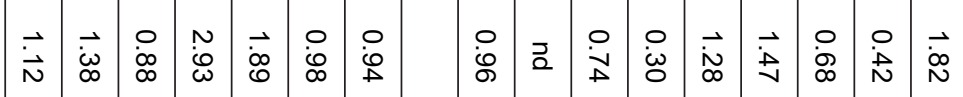

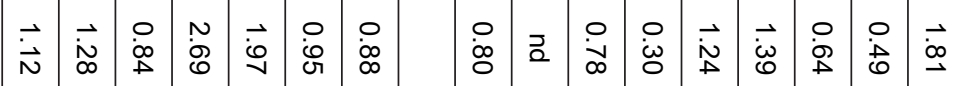

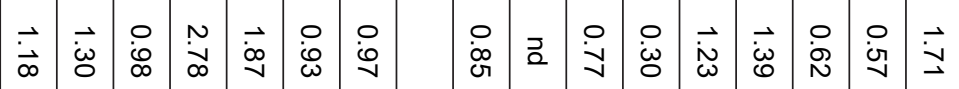

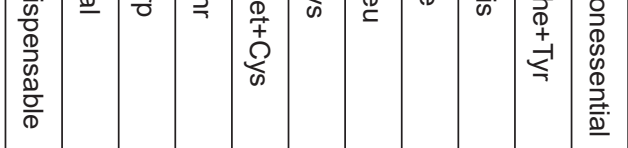

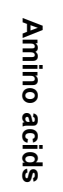

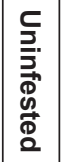

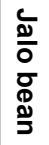

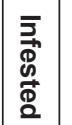

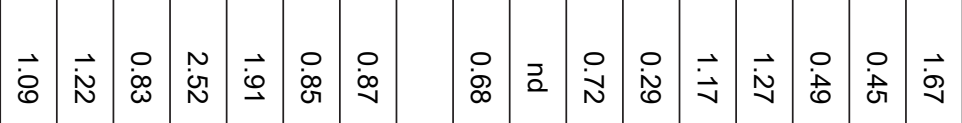

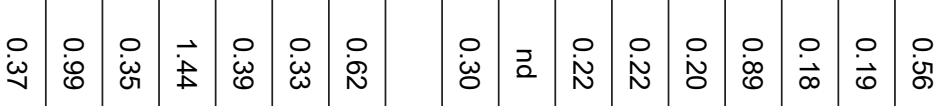

c…

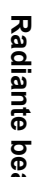

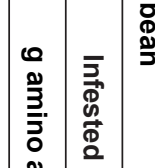

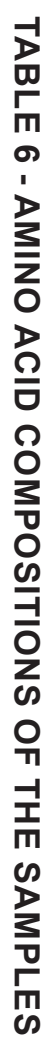

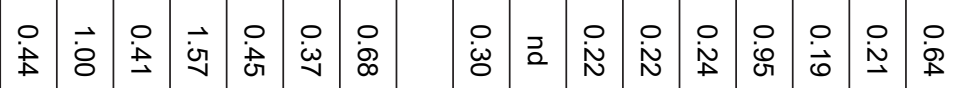

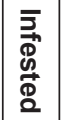

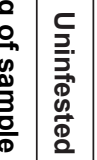

달.

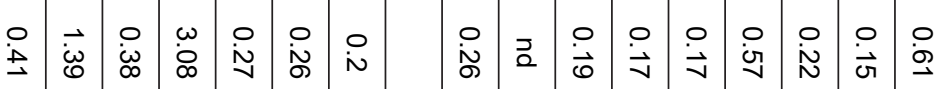

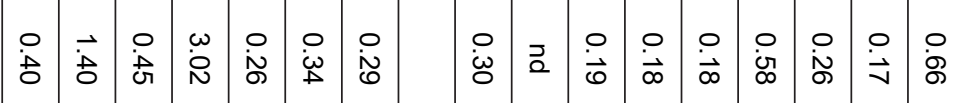




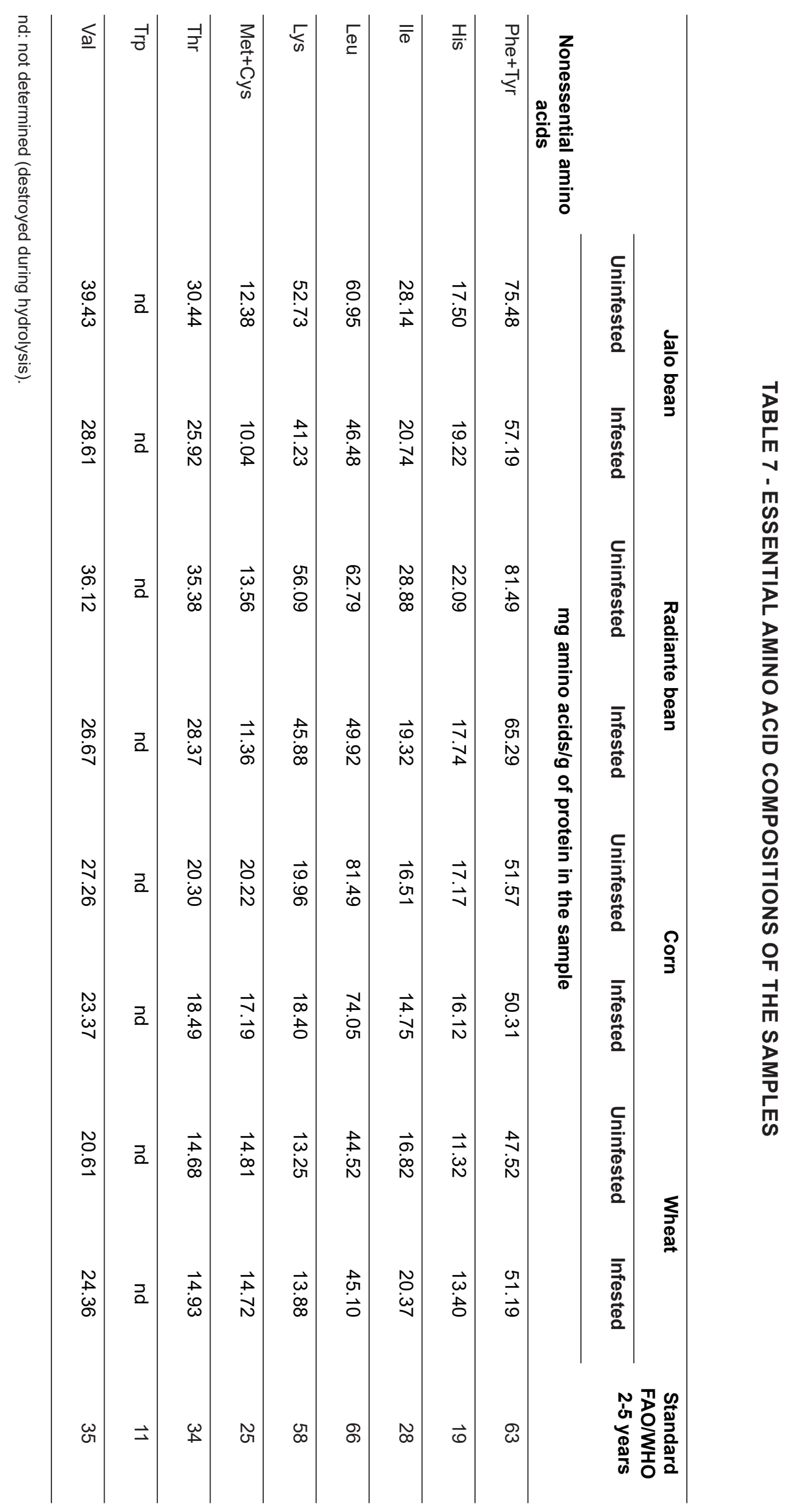




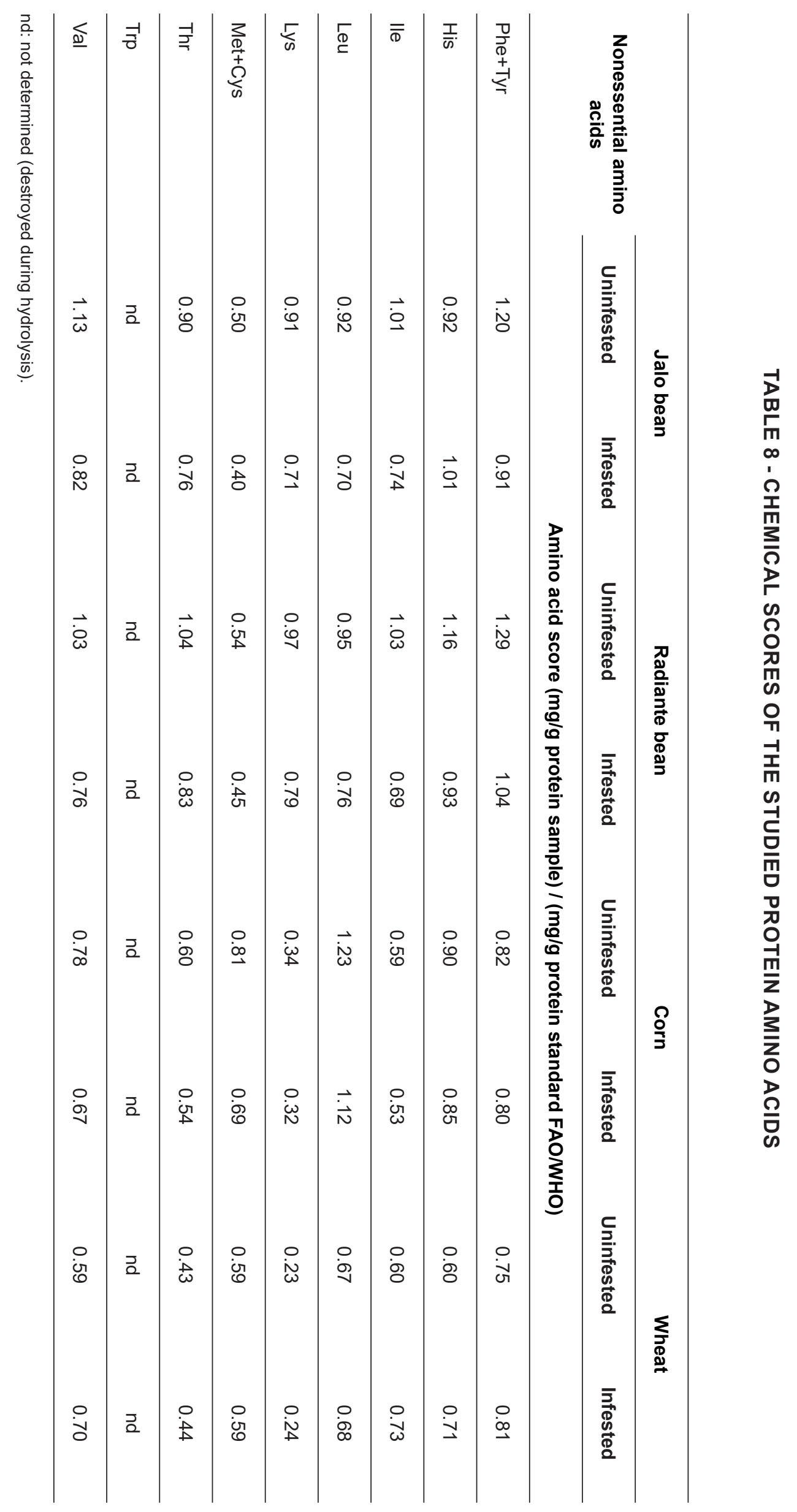




\section{TABLE 9 - VARIATION IN THE AMINO ACID CHEMICAL SCORES (EQ) BETWEEN INFESTED AND UNINFESTED GRAINS}

\begin{tabular}{lcccc}
\hline \multirow{2}{*}{ Nonessential amino acids } & \multicolumn{4}{c}{$\Delta$ EQ (EQ infested grain - EQ uninfested grain) } \\
\cline { 2 - 5 } Phe+Tyr & Jalo bean & Radiante bean & Corn & Wheat \\
\hline His & -0.29 & -0.26 & -0.02 & 0.06 \\
\hline Ile & 0.09 & -0.23 & -0.06 & 0.11 \\
\hline Leu & -0.26 & -0.34 & -0.06 & 0.13 \\
\hline Lys & -0.22 & -0.19 & -0.11 & 0.01 \\
\hline Met+Cys & -0.20 & -0.18 & -0.03 & 0.01 \\
\hline Thr & -0.09 & -0.09 & -0.12 & 0.00 \\
\hline Trp & -0.13 & -0.21 & -0.05 & 0.01 \\
\hline Val & nd & nd & nd & nd \\
\hline
\end{tabular}

nd: not determined (destroyed in the process of hydrolysis).

TABLE 10 - PROTEIN DIGESTIBILITY CORRECTED AMINO ACID SCORES (PDCAAS)

\begin{tabular}{llll}
\hline Protein source (limiting amino acid) & EQ & Digestibility & PDCAAS (\%) \\
\hline Jalo bean (Met + Cys) & 0.50 & 73.57 & 36.79 \\
\hline Jalo bean with insect (Met + Cys) & 0.40 & 74.19 & 29.68 \\
\hline Radiante bean (Met + Cys) & 0.54 & 71.66 & 38.70 \\
\hline Radiante bean with insect (Met + Cys) & 0.45 & 71.83 & 32.32 \\
\hline Corn (Lys) & 0.34 & 84.37 & 28.69 \\
\hline Corn with insect (Lys) & 0.32 & 84.34 & 26.99 \\
\hline Wheat (Lys) & 0.23 & 92.80 & 21.34 \\
\hline Wheat with insect (Lys) & 0.24 & 90.03 & 21.61 \\
\hline
\end{tabular}

PDCAAS $=$ first limiting amino acid $\mathrm{x}$ true digestibility obtained by animal experimentation .

Table 6 shows a reduction in almost all of the amino acids levels (per $100 \mathrm{~g}$ ) for infested bean samples compared to the uninfested bean samples. This decrease was not observed for the corn and wheat samples.

The variation in the amino acid chemical scores of the infested and uninfested samples is shown in Table 9. We observed a decrease in the chemical scores of corn and both beans varieties. However, the decrease was more pronounced in the bean varieties, which is in agreement with the reduction in PER and NPR values observed for bean varieties but not for corn and wheat (Table 4).

Generally, various proteins are differentially distributed within grains, and proteins having the highest nutritional quality (i.e., a more balanced amino acid content) are closer to the germ. Certain insects consume only certain parts of the grain (LALE and IGWEBUIKE, 2002). For example, some insects preferentially feed on the germ, thereby reducing the protein quality of the grain. Grain infestation also increases the level of uric acid and non-protein nitrogen, which reduces the 
nutritional quality of the grain (Modgil \& Mehta, 1997). However, a decrease in the protein quality of infested grains has not been observed in all previous studies, suggesting that the type of insect and grain composition determine the reduction in the protein quality of a grain. This suggests that there is a co-evolution between insects and plants. Thus, insects that have adapted to grains with higher protein contents have a greater dependence on this nutrient, consuming it in greater quantity and decreasing the protein quality of the grain. Matioli and Almeida (1979) reported that insects of the genus Sitophilus consume the endosperm of the grain, feeding mainly on carbohydrates and consuming a low level of protein.

\section{CONCLUSIONS}

Grain digestibility was not affected by insect infestation. However, the PER and NPR values decreased for beans, suggesting that the insects attacked these grains and used the essential amino acids of the beans. This difference was not observed for corn and wheat.

Insect infestation reduces the nutritional quality of grains. However, the insect type and grain composition influence this change in the quality, suggesting a co-evolution between insects and plants. Thus, insects that have adapted to grains with a higher protein content have a greater dependence on this nutrient, consuming it in greater quantity and decreasing the protein quality of the grains they attack.

Contamination of grains by insects can lead to nutritional and economic losses and can facilitate the growth of microorganisms.

\section{RESUMO}

\section{AVALIAÇÃO DA QUALIDADE PROTEICA DE GRÃOS DE FEIJÃO, MILHO E TRIGO ATACADOS POR INSETOS-PRAGA}

O ataque por insetos causam diversos prejuízos aos grãos, dentre eles a perda de peso do grão, o aquecimento e conseqüente deterioração, devido ao metabolismo do inseto, a perda do valor de mercado e a perda do valor nutritivo do alimento, em decorrência do consumo pelo inseto. O objetivo deste trabalho foi comparar a digestibilidade, escore químico, pontuação de aminoácidos corrigida pela digestibilidade das proteínas (PDCAAS), coeficiente de eficiência proteica (PER) e razão proteica líquida (NPR) das farinhas destes grãos infestados e não infestados. As farinhas dos grãos infestados apresentaram maior teor de nitrogênio. Observou-se que a presença do insetopraga não alterou a digestibilidade dos grãos analisados, porém houve redução do PER e do NPR para os grãos de feijão, fato que não foi observado para os grãos de milho e trigo. Foi observada uma redução mais acentuada nos teores de aminoácidos essenciais para os grãos de feijão do que para os grãos de milho e trigo. A qualidade nutricional de grãos é diminuída com o ataque de insetos, porém a família do inseto e a composição do grão influenciam esta alteração da qualidade.

PALAVRAS-CHAVE: INSETO-PRAGA; DIGESTIBILIDADE PROTÉICA; ESCORE QUÍMICO.

\section{REFERENCES}

1 ASSOCIATION OF OFFICIAL ANALYTICAL CHEMISTS - AOAC. Official methods of analysis of the Association of Official Analytical Chemists. 19. ed. Arlington: 2012.

2 ATHIÉ, I.; CASTRO, M.F.P.M.; GOMES, R.A.R.; VALENTINI, S.T. Conservação de grãos. Campinas: Fundação Cargil, 1998. $236 \mathrm{p}$. 
3 BARNEY, R.J.; SEDLACEK, J.D.; SIDDIQUI, M.; PRICE, B.D. Quality of stored corn (maize) as influenced by Sithophilus zeamais Mottsch and several management practices. Journal of Stored Products Research, v. 27, n. 4, p. 225-237, 1991.

4 BENDER, A.E.; DOELL, B.H. Note on the determination of net protein utilization by carcass analysis. British Journal of Nutrition, v. 11, n. 2, p. 138-143, 1957.

5 BRAGA, L.G.T.; LOPES D.C.; COSTA, N.M.B.; PEREIRA, J.S.; TEIXEIRA M.P. Uso de ratos de laboratório para determinar o valor nutritivo do milho em diversos níveis de carunchamento. Revista Brasileira de Zootecnia, v. 32, n. 2, p. 331-336, 2003.

6 BRASIL. Regras para análise de sementes. Brasília: Ministério da Agricultura, 1992. 365p.

7 FAO/OMS. INFORME DE UNA REUNIÓN CONSULTIVA CONJUNTA FAO/OMS/UNU DE EXPERTOS. Necessidades de energia y de proteínas. Ginebra, 1985. 220 p.

8 HENLEY, E.C.; KUSTER, J.M. Protein quality evaluation by protein digestibility corrected amino acid scoring. Food Technology, v. 4, n. 1, p. 74-77, 1994

9 JOOD, S.; KAPOOR, A.C. Effect of storage and insect infestation on protein and starch digestibility of cereal grains. Food Chemistry, v. 44, n.3, p. 209-212, 1992.

10 JOOD, S; KAPOOR, A.C; SINGH, R. Biological evaluation of protein quality of maize as affected by insect infestation. Journal of Agricultural of Food Chemistry, v. 40, n. 12, p. 2439-2442, 1992.

11 JOOD, S; KAPOOR, A.C; SINGH, R. Biological evaluation of protein quality of sorghum as affected by insect infestation. Plant Foods of Human Nutrition, v. 43, n. 2, p. 105-114, 1993.

12 LALE, N.E.S.; IGWEBUIKE, J.U. Field infestation of Faidherbia (Acacia) albida (Del.) A. chew. pods by stored product Coleoptera in the Nigerian Savanna and effect of infestation on nutrient quality. Journal of Arid Environments, v. 51, n. 1, p. 103-112, 2002.

13 MATIOLI, J.C.; ALMEIDA, A.A. Alterações nas características químicas de grãos de milho causadas pela infestação de Sitophilus oryzae (L., 1973). III- Nitrogênio total e carboidratos. Revista Brasileira de Armazenamento, v. 4, n.1, p. $57-68,1979$

14 MILLWARD, D.J., LAYMAN, D.J.; TOMÉ, D.; SCHAAFSMA, G. Protein quality assessment: impact of expanding understanding of protein and amino acid needs for optimal health. American Journal of Clinical Nutrition, vol. 87, n.5, p. 1576S-1581S, 2008

15 MODGIL R.; MEHTA, U. Effect of infestation (Callosobruchus chinensis L.) of chick peas (Bengal gran) on biological utilization of proteins. Nahrung, v. 41, n. 4, p. 236-238, 1997

16 MODGIL R.; MEHTA, U. Protein quality of chickpea (Cicer arietenum) with different grades of Callosobruchus chinensis L. infestation. . Plant Foods of Human Nutrition, v. 44, n. 2, p. 157-162, 1993.

17 PIRES, C.V.; OLIVEIRA, M.G.A.; ROSA, J.C.; COSTA, N.M.B. Qualidade nutricional e escore químico de aminoácidos de diferentes fontes proteicas. Ciência e Tecnologia de Alimentos, v. 26, n.1, p. 179-187, 2006.

18 RAMOS-ELORDUY, J.; MORENO, J.M.P.; PRADO, E.E.; PEREZ, M.A.; OTERO, J.L.; GUEVARA, O.L. Nutritional value of edible insects from the State of Oaxaca, Mexico. Journal Composition and Analysis, v. 10, n. 2, p.142-157, 1997.

19 REEVES, P.G.; NIELSEN, F.H.; FAHEY, G.C. AIN-93 purified diets for laboratory rodents: final report of the American Institute of Nutrition ad hoc Writing Committee on the reformulation of the AIN-76A rodent diet. Journal of Nutrition, v. 123, n. 11, p. 1939-1951, 1993.

20 RESENDE, O.; CORREA, P.C.; OLIVEIRA, M.G.A.; SANT'ANA, R.C.O.; MENDES, F.Q. Avaliação da qualidade tecnológica e proteica do feijão durante o armazenamento. Revista Brasileira de Armazenamento, v. 32, n.1, p. 01-13, 2007.

21 VERKERK, M.C.; TRAMPER J.; van TRIJP, J.C.M.; MARTENS, D.E. Insect cells for human food. Biotechnology Advances, v. 25, n. 2, p. 198-202, 2007.

\section{ACKNOWLEDGMENTS}

This study was financially supported by CNPq and FAPEMIG. 